DOI: http://dx.doi.org/10.22201/iie.18703062e.2010.96.2301

\author{
GIULIO CARLO ARGAN ${ }^{\dagger}$
}

\title{
La retórica aristotélica y el barroco El concepto de persuasión como fundamento de la temática figurativa barroca ${ }^{\mathrm{I}}$
}

$\mathrm{E}$ STA INVESTIGACión PRETENDE comprobar que las contradicciones entre el arte y la cultura del barroco, si bien ya fueron objeto de crítica en varias ocasiones, prácticamente no existen, ya que en la época del barroco se presentan como una unidad histórica con definiciones precisas. En contraste con el neoplatonismo de Miguel Ángel, el barroco significa una comprobación del pensamiento aristotélico, no sólo respecto a la ya investigada influencia de la Poética, sino, sobre todo, en cuanto a la Retórica.

Durante el siglo xvir, la interdependencia mutua de "pittura-poesia" se transforma en la interdependencia "pittura-eloquenza". El término poesía ha experimentado, desde Tasso, un cambio profundo, de tal manera que abandonó todos los asuntos humanísticos en favor del fomento de connotaciones éticas y religiosas. En esta área semántica, también se reanima el tema "Ut pictura poesis" en el círculo bolonés de Carracci.

Si aceptamos esa tesis del arte como retórica, hay que conocer el fin de aquella retórica. En este sentido, el arte se relaciona con los asuntos religiosos de su tiempo y se podría decir que el arte del barroco pretende transformar el ideal religioso en un ideal burgués, lo cual quiere decir: convertirlo en norma para la vida social y política. Sólo cuando uno transfiere la noción del barroco hacia

I. Texto en alemán, traducido al español por Peter Krieger. Véase la versión original Giulio Carlo Argan, "La Rettorica Aristotelica ed il Barocco. Il Concetto di Persuazione come Fondamento della Tematica figurativa barocca”, Kunstchronik, núm. 8, I955, pp. 91-93. 
el ambiente de lo ético y lo social es posible abandonar la interpretación negativa del arte barroco, como lo hizo Croce. En el sentido aristotélico, el poder de convicción es el fundamento verdadero de las relaciones humanas. Con esto, la relación del artista, quien se propone y actúa para convencer, con el receptor, como una persona "ajena", recibe un enfoque nuevo. Desde esa perspectiva, la teoría de los afectos, como Aristóteles la demuestra en su segundo libro de la Retórica, se convierte en la condición fundamental para que el arte sea capaz de cumplir su tarea de convencer.

Además, a propósito de la "retórica", surge la noción de que lo probable no es distinguible de lo verdadero, ya que ambos, respecto a los fines de convencimiento, producen los mismos efectos. Lo probable aun interesa más que lo verdadero. Aquí gana especial importancia la manera, la técnica del pintor, quien tiene la tarea de producir la ilusión de lo probable. La técnica debe mantenerse escondida, para no revelar el truco visual aplicado. De esta manera, a la técnica de la invención se sobrepone otra: la espontaneidad de la presentación.

Finalmente, el luminarismo caravaggesco no es otra cosa que una presentación bien definida del poder enorme de convicción compuesto por pruebas y ejemplos. Es posible describir, en términos prácticos, las contraposiciones de la pintura de los Carracci con la de Caravaggio, como una diferencia entre "poesía", entendida como corriente emocional, y "poesía", como historia revivida en la naturaleza. En ambos casos encontramos, en el nivel religioso, las variaciones establecidas de los temas tradicionales, pero todavía no una tendencia propagandística claramente definida. Ésa se expresa hasta la pintura de Reni. En la Crucificación de Pedro, pintada dos años después del cuadro correspondiente de Caravaggio, se transforma el gesto "realista" de san Pedro de Caravaggio en uno ideológico que insinúa la importancia religiosa del martirio. Reni quiere ser más "moralista" que Caravaggio y su figura de san Pedro se transforma en la imagen de una idea, que en primer lugar es de carácter ético. Para Reni, la invención, el tema, la figura, y con esto también "lo bello", sólo son "ideas". Sin embargo, se trata de poner un límite: tiene el mismo sentido que el dogma en el campo religioso. Poner ese límite permite, empero, en un área cerrada, definiciones claras y distinciones éticas sutiles.

Existe entonces, de igual manera, una libertad ética y artística del cuadro. Por eso, la técnica mimética de Reni evita los grandes efectos para utilizar medidas más simples. Con eso, Reni no pretende confirmar o fundar un principio o dogma: porque la Iglesia católica ya había superado las fases más peligrosas de su lucha contra la Reforma protestante, y la autoridad y la verdad de 
los dogmas no fueron objeto de discusión. Pero surgió la necesidad de enseñar a los hombres, de comportarse según esos dogmas. La forma artística significó, entonces, el medio para convencer de que la vida humana sólo se cumple cuando respeta el límite de un convenio ideológico y ético. Y de hecho es aquel proceso de "convencer" por el cual el ideal religioso, que por tradición se asocia con el arte, se transforma en un ideal burgués.

A esta transformación corresponde en el sentido estético estricto la transformación del término de "lo bello" en algo "de calidad". El remplazo de "lo bello" por "la calidad", como valor estético que se cumple sin restricciones en la creación artística por una norma canónica, lo comprueba a principios del siglo XVII el teórico inglés de arte Richardsson. La acuñación de este término, de enorme importancia para la historia de la estética y de la teoría del arte, se vincula cercanamente con la del "gusto", también entendido como la calidad que el artista comparte con su público, y que constituye un elemento de conexión entre uno y otro.

Sobre esta línea histórica se revela la época estilística del barroco en su unidad como fase necesaria de un desarrollo del que nace y se configura la cultura europea moderna.

\section{s \\ Comentarios de Elisa Vargaslugo}

El gRAn ESCRITOR y CRÍtico De ARTe Carlo Giulio Argan ha dedicado especial atención en sus numerosos libros y artículos a explicar la naturaleza del arte barroco, no sólo como un género de las artes figurativas sino como recurso formal para expresar inquietudes políticas, anhelos sociales y, a la vez, compromisos religiosos. En su artículo, titulado "La retórica aristotélica y el barroco. El concepto de persuasión como fundamento de la temática figurativa barroca", resalta la importante relación que puede darse entre este arte y el arte de la retórica, lo que pone de manifiesto la influencia del pensamiento aristotélico en los artistas barrocos a partir del siglo XVII.

Aristóteles consideraba que el pensamiento poseía una estructura eminentemente visual y que entre la percepción y el pensamiento se encuentra la ima- 
ginación, facultad que para este filósofo constituía el punto de contacto entre el hombre y el mundo, entre lo particular y lo universal. Y vale la pena recordar que el arte barroco es esencialmente imaginativo. Añade Argan que si se acepta la tesis del arte como retórica, puede afirmarse que el arte barroco pretendía transformar el ideal religioso en un ideal burgués, o sea, convertirlo en norma para la vida social y política.

Con estas cortas frases queda clara la intención que animó el trabajo de Argan para presentar el concepto de persuasión "como fundamento de la temática figurativa del arte barroco", vista ésta como novedoso esfuerzo imaginativo para advertir, impresionar, informar, atraer y desde luego convencer — "con argumentos y razones", o sea, persuadir-, respecto a las circunstancias sociales, políticas y religiosas de la época, como efectivamente sucedió. Desde luego, en varias creaciones barrocas mexicanas quedan ampliamente probadas estas teorías del maestro italiano.

El primer caso notable fue la inmediata conversión de la imagen de santa Rosa de Lima, primera santa americana - beatificada en I668 y canonizada en I67I-, en la bandera política de los criollos mexicanos, quienes, "olvidando" que era peruana, la llamaron, entre otros apelativos, "lustroso honor de la Nueva España” y, en consecuencia, su imagen, como señal de americanidad, se representó y colocó en las portadas de los templos de la Nueva España, de sur a norte del Virreinato. ${ }^{2}$

Otra obra sumamente interesante y reveladora es la gran pintura titulada $E l$ triunfo de Nuestro Padre san Pedro, que cubre uno de los muros de la sacristía de la Catedral de la ciudad de México, encargada por el cabildo de dicha catedral al renombrado pintor Cristóbal de Villalpando en I686. De acuerdo con Nelly Sigaut, ${ }^{3}$ tal obra es parte de un programa relacionado con la realidad social novohispana, tal como ella lo demuestra. El cabildo, cuerpo colegiado y "factor de unidad en la vida de la catedral”, según informa Sigaut, estaba formado por criollos en su mayor parte, posiblemente en su totalidad. Y, como ha quedado ampliamente probado en los estudios históricos de la época colonial, el crecimiento de las legítimas ambiciones políticas de la sociedad criolla, a esas alturas del siglo XVII,

2. Elisa Vargaslugo, "Proceso iconológico de santa Rosa de Lima", en Actes du XLIIe Congrès International des Américanistes, París, I976, vol. X.

3. Nelly Sigaut, "El concepto de tradición en el análisis de la pintura novohispana. La sacristía de la Catedral de México y los conceptos sin ruido", en Tradición, estilo o escuela iberoamericana. Siglos XVI-XVIII, México, Banamex/Organización de Estados Iberoamericanos/Banco de Crédito del Perú, 2004, pp. 207-253. 
la había llevado a una fuerte y siempre creciente rivalidad con el gobierno español, que, dicho sucintamente, culminó en I8 io con la guerra de Independencia.

En enero de 1684 comenzaron las iniciativas y las discusiones acerca de la ornamentación de la sacristía de la catedral metropolitana. Los miembros del cabildo, que lo eran a la vez de la Congregación de San Pedro, lograron, como puede verse, una novedosa y magnífica composición para representar con toda gala de personajes, de formas, giros de color y movimiento, el "Triunfo" de ese importante santo, quien aparece acompañado de significativos personajes femeninos que representan la Ecclesia, la Fama, la Victoria y la Sabiduría, entre otros. Pero entre dichas imágenes de los valores tradicionales de la religión destaca "una figura femenina en el ángulo inferior izquierdo", con rostro moreno, cuyos largos aretes perforan los lóbulos de sus orejas, y con un discreto bezote en el labio inferior de su boca. En las manos lleva una corona tradicional y su frente está ceñida por una tiara con una águila parada sobre un nopal. En uno de sus brazos luce un vistoso penacho multicolor. Como asegura Sigaut, no cabe duda de que esta mujer representa a la Nueva España, patria de criollos. $\mathrm{Su}$ aspecto "racial" dentro de este carro triunfal, al lado de una mujer de tez muy blanca que representa "a la vieja España", intenta cuando menos denunciar, para mostrar la igualdad política de las dos naciones ante san Pedro, vicario de Cristo, y así también refrendar la fuerza e importancia del clero secular.

Finalmente, creo haber destacado el carácter suasorio del magnífico conjunto de retablos del templo de Santa Prisca de Taxco, hecho a la medida del gusto, el pensamiento y el sentimiento más íntimo del rico minero burgués José de la Borda. En esas magníficas tallas de novedosos diseños se muestran, mediante un programa triunfalista, incruento, la glorificación e importancia religiosa del martirio y, para buscar la solución a los problemas de la vida cotidiana de aquella sociedad, se encuentran milagrosos santos protectores a los que es posible recurrir, cuya presencia equivale a la de un "equipo de primeros auxilios". La representación de estos temas y la de otros más que se encuentran dentro del proyecto ornamental del templo se hallan colocadas sólidamente dentro de la composición de una magnífica estructura eclesiástica con un desarrollo formal creciente y triunfalista, de acuerdo con la frase "Dios a darle a Borda y Borda darle a Dios", que señaló el triunfo económico y práctico del espíritu burgués de José de la Borda. ${ }^{4}$

4. Elisa Vargaslugo, La iglesia de Santa Prisca de Taxco, México, Universidad Nacional Autónoma de México-Instituto de Investigaciones Estéticas/Coordinación de Humanidades/Coordinación de Difusión Cultural/Seminario de Cultura Mexicana, I999. 
DOI: http://dx.doi.org/10.22201/iie.18703062e.2010.96.2301

I I 6 ELISA VARGASLUGO

Basten estos ejemplos de la capacidad y poder del arte barroco novohispano para expresar las inquietudes políticas de los criollos guiados por sentimientos burgueses de autodeterminación y de independencia, todo lo cual demuestra la fuerte motivación "moderna" manifiesta en el hondo espíritu católico que la Iglesia había sembrado en la sociedad.

Con este enfoque resultan de sumo interés estas páginas de la obra de Giulio Carlo Argan traducidas generosamente por Peter Krieger para beneficio de los estudiosos del arte barroco. कs 